\title{
Sabatähed, mis tegid ajalugu
}

\section{Erik Tago}

Maailm on sabatähti täis. Päikesesüsteemi ääremaadel ja võibolla kaugemalgi on neid miljardeid. Tuleb vaid oodata, millal mõni neist jälle Päikesele läheneb, soojenedes aurama hakkab ja seeläbi nähtavaks saab.

Komeetide üleskirjutatud ajalugu ulatub vähemalt kolme aastatuhande taha. Juba 11. saj enne Kristust tehti Hiinas ja Babüloonias ülestähendusi sabaga tähtede kohta (mõnedel andmetel juba 15. saj e Kr), mõni sajand hiljem ka Kreekas. Neid nimetati enamasti "luua"-, "põõsas"- või "juustega tähtedeks".

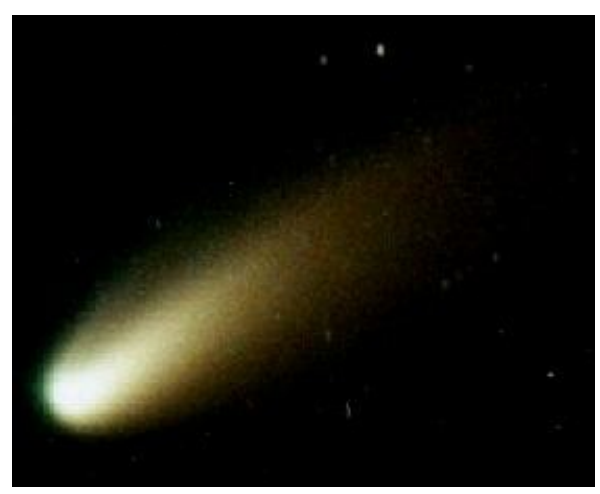

Kolme aastatuhande jooksul on komeete registreeritud ligi $\mathbf{7 0} 000$ korral. Tänapäeva teleskoopidega on sabatähti võimalik avastada mõnikümmend tükki aastas. Neist vaid üks kolme aasta kohta on nähtav ka palja silmaga ning üks komeet kümne aasta kohta on nii hele, et pälvib avalikkuse suuremat tähelepanu. Seega mõnisada kõige heledamat komeeti on ühel või teisel viisil ajaloos jäädvustatud.

Sabatähed on osutunud hämmastavalt mõjuvõimsateks taevakehadeks. Enamasti on komeetide ilmumist võetud kurjakuulutava endena, sõja, valitseja surma, õnnetuse või mõne muu halva sündmuse märgina. Miks on taevanähtustest just komeedid osutunud sellisteks hirmuvalitsejateks? Selle küsimuse üle murdis pead juba näiteks Seneca Antiik-Roomas. On ju päikesevarjutused ja virmalised samavõrd hämmastavad ja kaunid. Ehk on selle põhjuseks komeetide etteennustamatu ilmumine. Seejuures võivad nad nädalateks või isegi pikkadeks kuudeks jääda paistma üle taevavõlvi, nii hirmuäratavatena, aga samal ajal ka nii kauneina ja jahmatavatena.

Sabatähtede maailmas on vaieldamatu liider - Halley komeet. Juba mitukümmend korda, perioodiga ligi 76 aastat, on see komeet lähenenud Päikesele alates sellest ajast, kui inimesed hakkasid komeete üles tähendama. Koos teiste heledate komeetidega on ta inimeste arvates mõjutanud saatusi ja ehk "teinud" koguni Suurt Ajalugu.

Olgu siinkohal esitatud mõned neist:

\begin{tabular}{|c|c|}
\hline KOMEET & SÜNDMUS \\
\hline 44. $\mathrm{a} \mathrm{eKr}$ & $\begin{array}{l}\text { Julius Caesari surm Brutuse käe läbi; vahetult pärast seda ilmub taevasse komeet, mida } \\
\text { peetakse selle ajaloolise sündmusega seotud märgiks. Augustus jäädvustab hiljem selle } \\
\text { komeedi Caesarile pühendatud mündil. Lihtrahvas arvab, et komeedi kujul lahkub } \\
\text { Caesari hing jumalate maailma. Algab Rooma impeeriumi aeglane aga kindel langus. }\end{array}$ \\
\hline $\begin{array}{l}\text { 1066. a } \\
\text { (Halley) }\end{array}$ & $\begin{array}{l}\text { komeedi ilmumine tekitab hirmu Inglise kuningas Haroldis; vastupidi, William } \\
\text { Vallutaja Normandias peab komeeti kindlaks märgiks, et ta peab vallutama Inglismaa. } \\
\text { Nii juhtubki, samal aastal toimub Hastingsi lahing mille William võidab. Inglismaa } \\
\text { saatus on sellega määratud, pannes aluse tulevasele Briti impeeriumile. }\end{array}$ \\
\hline 1222. a & Tshingis-Khan peab ilmunud komeeti endeks, et ta peab maailma vallutama hakkama. \\
\hline
\end{tabular}


Järgnevate sajandite jooksul suudavad mongolid-tatarlased vallutada pool Vanast (Halley) Maailmast, pannes paika ida-lääne piiri. Ka Eestimaa saatus on on nende vallutustega suuresti määratud, asetades meid ida-lääne piirile, kord ühele, kord teisele poole sellest.

1456. a

(Halley)

Katk, epideemiad; süüdi on nn. "komeeditõbi", mida sabatähed külvavat.

\section{6. a Maavärin Konstantinoopolis}

1665. a. Katkutaud; Londoni suur põlemine 1666. a.

1773. a Pariisis suur paanika; arvatakse, et komeet hävitab Maa, ennustatakse maailma lõppu. Napoleon pidas selle aasta heledat komeeti halvaks endeks oma järgneva aasta

1811. a nurjunud sõjakäigule Venemaale, millega algas tema langus. 1811. a harukordselt head viinamarjasaaki peetakse ka sama komeedi poolt põhjustatuks.

Mida lähemale me jõuame tänapäevale, seda ratsionaalsemaks muutub suhtumine komeetidesse.

Kaunid on nad olnud vaadata sellegipoolest. Mõned komeetidest on astronoomidele olulised seetõttu, et on aidanud meil mõista, mis asi on üldse komeet, mõned on olnud aga eriti väljapaistvad.

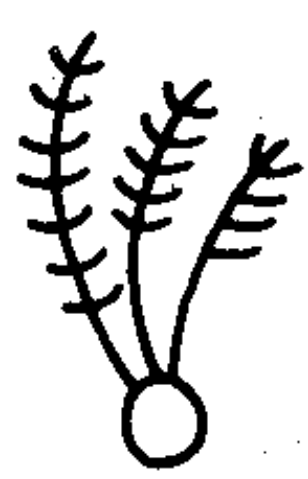

Varasemaid ülestähendusi ongi tehtud eriti hoolikalt Hiinas. Ka esimene kindel ülestähendus Halley komeedist(240. a eKr) on pärit sealt.

Ei maksa eriti naeruvääristada seda ebausku ja hirmu, mida keskajal inimesed tundsid sabatähtede ees. Valitses ikka veel peaaegu 2000 aastat vana Aristotelese seisukoht, et komeedid on atmosfäärinähtus - maa sisemusest vabanenud põlev gaas. Seda kinnistas ka astroloogia, mis komeedi ilmumise kohta mingis taeva osas seostas kindlat liiki hädadega. Muistses Hiinas arvati sõltuvat häda jälle sellest, millise kujuga oli komeedi saba.

Alles 1577. a tõestas Taani astronoom Tycho Brahe, et komeet ei ole maine nähtus, vaid on kindlasti tunduvalt kaugemal kui Kuu.

1682. a komeet saab nimeks Halley, kui Edmond Halley, Newtoni kaasaegne ja mõttekaaslane arvutab komeedi orbiidi, kasutades Newtoni teooriat. Uurides andmeid 1531.a. ja 1607.a. komeetide kohta, leidis ta, et see on sama komeet. 1758. aasta Halley komeet on esimene ette ennustatud komeet

Üks väljapaistvamaid komeete ilmus 1843. a Ta möödus väga lähedalt Päikese pinnast, oli ligi 60 korda heledam täiskuust ja päeval Päikese kõrval näha. Ka saba oli tal seni pikim - ligi 300 milj. kilomeetrit, s. o. 2 astronoomilist ühikut. 1882. a komeet on hinnangu järgi kõige heledam ülestähendatuist $(m=-18)$.

Ka kõige värskemad komeedid on igatpidi väärikad: 1996. a (Hyakutake) komeet oli harukordselt pika

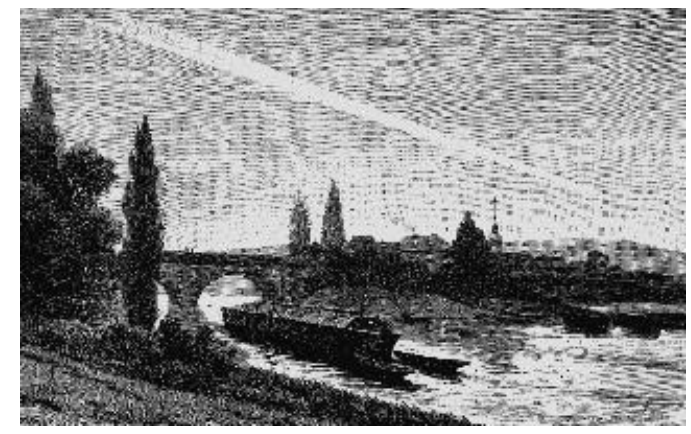
sabaga, käesoleva aasta komeet (Hale-Bopp) on selle sajandi heledamaid. Tähtsad on nad meile ka selle poolest, et MEIE neid näha saame. 
Tänapäeval on komeedid suuresti kaotanud oma halva kuulsuse kuigi veel 1910. a komeeti võeti mõnel pool hirmuga vastu gaasimaskides. Aga siiski, sabatähed võivad varjata üht suurimat saladust - maise elu päritolu saladust. Võisid ju komeedid, mis sisaldavad jääd ja süsinikuühendeid, Maale lähenedes kanda siia vett ja külvata orgaanilisi ühendeid. Kui aga mõni komeetidest peaks Maale kukkuma, võivad sellesama elu tingimused siin oluliselt halveneda. Õnneks ei taba komeedid sihtmärki Maad tihti - vaid paar korda 100 miljoni aasta kohta.

Igatahes tasub sabatähtede vastu jätkuvalt huvi tunda!

\section{Kirjandus}

Yeomans, D.K. 1991. Comets. Wiley Science Editions.

Bortle, J.E. Great Comets in History. Sky \& Telescope, vol 93, No 1 (jaan 1997), 1k 44-50. Meier, M.V. 1903. Mirozdanie. S-Peterburg, lk 197-237.

Yau, K. Comets Now and Then. Mercury, nov-dets 1996, lk 20.

NB! Komeetidest võid lugeda veel ka Tartu Tähetorni www-lehelt $\underline{h t t p: / / w w w . o b s . e e ~}$ 